\title{
Nastojanja nadbiskupa Stadlera oko uvođenja kongrue za katolički kler u Bosni i Hercegovini od 1882. do 1910. godine
}

MiLeNKO KREŠIĆ

Katolički bogoslovni fakultet u Sarajevu

Catholic Theological Faculty of Sarajevo

E-mail:milenkokresic1@gmail.com
UDK: 272-789.32/.33(497.6)(091)“1882/1910"

272-726.2 Stadler J.

Izvorni znanstveni rad

Primljeno: 8. prosinca 2020.

Prihvaćeno: 29. lipnja 2021

\section{Sažetak}

U radu se obrađuje nastojanje vrhbosanskoga nadbiskupa Josipa Stadlera oko uvođenja i uređenja kongrue (prikladnog uzdržavanja svećenika) u Vrhbosanskoj nadbiskupiji, odnosno Bosni i Hercegovini u vremenu od 1882. do 1910. po uzoru na ostale zemlje Monarhije, tj. uz dogovor s državnim vlastima. U prvom poglavlju obrađeni su Stadlerovi pokušaji oko uvođenja kongrue od 1882. do 1901. U drugom poglavlju obrađeni su pokušaji rješenja ovoga pitanja u sklopu rješavanja tzv. "katoličke autonomije". U trećem poglavlju opisan je pokušaj rješenja u dogovoru sa Zemaljskom vladom te u četvrtom pokušaj rješenja preko Svete Stolice. Usprkos svim Stadlerovim pokušajima, koji su trajali gotovo neprestano, u različitom intenzitetu, kongrua na kraju nije uvedena zbog protivljenja franjevaca koji su procijenili da bi njezinim uvođenjem više izgubili nego dobili.

Ključne riječi: kongrua; nadbiskup Stadler; franjevci; Zemaljska vlada; Bosna i Hercegovina, Sveta Stolica. 


\section{Archbishop Stadler's efforts regarding the introduction of congrua for the Catholic clergy in Bosnia and Herzegovina from 1882 to 1910}

Original scientific article Received: 8 December 2020

Accepted: 29 June 2021

\section{Summary}

The paper deals with Archbishop Stadler's efforts regarding the introduction and regulation of congrua (adequate support for priests), first in the Roman Catholic Archdiocese of Vrhbosna (and Banja Luka till 1884) and later in the entire Ecclesiastical Province of Vrhbosna in the period from 1882 to 1910 following the example of other Monarchy countries, i.e. in the agreement with the state authorities. The first chapter deals with Stadler's attempts to introduce congrua from 1882 to 1901. Throughout this period, he tried to solve the problem in agreement with the Bosnian Franciscans, who almost exclusively, especially at the beginning, comprised the pastoral clergy of the mentioned Dioceses, as well as with the suffragan bishops. He had acceptable support from the bishop, but the problem was not solved because Bosnian Franciscans were not interested for its solving. The second chapter deals with the attempts to solve this issue in the framework of addressing the so called "Catholic autonomy". They lasted from 1905 to 1909. Joint minister of finances, I. Burián was at his disposal then, as well as the agreement of the suffragan bishops, but he did not have the consent of the Franciscan Province of Bosnia administration that requested "parity" in relation to bishops regarding making decisions for introduction and distribution of congrua. As that was contrary to canon law for Stadler, it was unacceptable for Bishop Marković. Stadler then suggested to the government a draft of the congrua arrangement that was very close to the Franciscan attitude, but since the government did not accept the entire autonomy project, they also did not accept the proposal of the congrua arrangement. In June 1909 Stadler had a new proposal for the government regarding the congrua arrangement. He had a consent of Bishop Marković, but not of Bishop Buconjić and Bosnian Franciscans. At that moment it was clear why Franciscans were rejecting congrua. They thought that their incomes would be decreased with the intro- 
duction of congrua, which could endanger the existence of their monasteries and educational institutes. The third chapter deals with Stadler's attempt to make the agreement with the Land Government regarding the congrua introduction. When it was seen that the congrua could not be introduced for all the clergy due to oppositions of the Franciscans and Bishop Buconjić, the Government, who thought this issue should be solved, suggested Stadler to limit introduction of congrua only on secular clergy. Although Stadler made some steps in that sense (sent to the government reports of diocesan parishes as the confirmation that the faithful wanted congrua instead of parish-priest fees) conditions set by the government or ministries from Vienna were not eventually acceptable for Stadler. Namely, the minister required that the lay faithful, who should be taxed, have a decisive role in the congrua arrangement, as it was the case with the Serbian Orthodox and Muslims. According to Stadler that was against canonical norms. The fourth and the last chapter deals with Stadler's efforts to make pressures on Franciscans through the Holy See and that they ask for the introduction of congrua. The Holy See estimated that this issue caused division among the clergy in Bosnia and Herzegovina and decided to examine it before making final decision. He entrusted the issue to Apostolic Delegate P. Bastien, whom he sent to Sarajevo at the end of 1910.

Keywords: congrua; Archbishop Stadler; Franciscans; Land Government; Bosnia and Herzegovina; Holy See.

\section{Uvod}

Kongrua dolazi od latinskoga congrua sustentatio - prikladno uzdržavanje ili portio congrua - prikladan dio, što konkretno predstavlja dostatno primanje za pristojno uzdržavanje svećenika. Radi se o srednjovjekovnoj praksi koja se odnosila na "vikare" koju je Tridentski koncil (1545.-1563.) proširio na biskupe i župnike te pravo nadzora nad pitanjem kongrue povjerio biskupima. ${ }^{1}$ Odredbe Tridenta preuzeo je Zakonik kanonskog prava iz 1917. Ante Crnica u Priručniku kanonskog prava Katoličke Crkve iz 1945. kongruu definira ovako: "Župnik ima pravo na pristojno uzdržavanje (congrua sustentatio) kao nagradu za svoj rad. Tu nagradu daje mu u prvom redu nadarje (beneficium), koje

1 Herbert Kalb, "Kongrua", u: Lexikon für Theologie und Kirche, VI., Herder, Freiburg im Breisgau, 2006., str. 252-253. 
Milenko Krešić - Nastojanja nadbiskupa Stadlera oko uvođenja kongrue...

je spojeno sa župničkom službom i koje dobiva pri preuzimanju službe. Gdje nema nadarja ili je nedovoljno, nadoknađuje ga doprinos iz državnog vjerskog pologa (fonda), podavanja sa strane vjernika (redovina, lukno, bir, poreština) koja se daju bilo u naravi bilo u gotovini."2

Krajem 19. stoljeća, tj. u Stadlerovo vrijeme, u većini europskih zemalja (Landes) prikladno uzdržavanje svećenika bilo je uređeno ili kroza zakon o kongrui ili kroz neki drugi zakonski akt. U Austriji je postojao zakon o kongrui koji je konačan oblik dobio 1898. U Ugarskoj nije postojao zakon o kongrui ali su svećenička primanja bila uređena zakonskim člankom XIV. iz 1898. U Hrvatskoj također nije postojao zajednički zakon o kongrui ali su svećenička primanja bila uređena različitim zakonskim aktima za pojedine dijelove zemlje: bivšu Vojnu krajinu, civilnu Hrvatsku i Senjsko-modrušku biskupiju. ${ }^{3}$

U Bosni i Hercegovini, koje su bile pod osmanskom vlašću, župnici su se uzdržavali od priloga vjernika. Od vremena do vremena crkvene bi vlasti propisivale koliko su vjernici bili dužni davati svojim župnicima, ali kako nije postojao jasan zakonski okvir, ovakav je način pružao priliku za mnoge zloporabe bilo od vjernika koji nisu propisano davali svojim župnicima ili od župnika koji bi na neprikladan način utjerivali od svojih vjernika ono što su im oni trebali ili što su župnici mislili da bi im oni trebali dati.

Postavši vrhbosanskim nadbiskupom 1881. godine Josip Stadler, dotadašnji profesor na zagrebačkom Bogoslovnom fakultetu, nastojao je ovo pitanje urediti kako bi se gore navedene zloporabe izbjegle i kako bi župnici, tamo gdje to nije bilo moguće od primanja vjernika, ipak pristojno živjeli.

Pitanjem kongrue za katolički kler u Bosni i Hercegovini do sada su se, koliko je poznato autoru, izravno bavili prof. don Petar Vrankić i prof. fra Velimir Blažević te djelomično, samo kada je riječ o pitanju autonomije, Luka Đaković. Prof. Vrankić u svojoj knjizi na njemačkom jeziku Religion und Politik in Bosnien und der Herzegowina (1878-1918), koristeći razne izvore, vatikanske i sarajevske: nadbiskupijske i franjevačke, posvetio je ovom pitanju jedno poglavlje kao i fra Velimir Blažević u svojoj studiji Bosanski franjevci i nadbiskup dr.

2 Ante Crnica, Priručnik kanonskog prava Katoličke Crkve, Franjevačka visoka bogoslovna škola Makarska, Zagreb, 1945., str. 97.

3 Kongruafrage in BOSNIEN und HERCEGOVINA - Studie, Arhiv Bosne i Hercegovine (ABiH), Zemaljska vlada u Sarajevu (ZVS), Präesidum (Präs.), 4151/1912., str. 4-10. 
Josip Stadler koji je, za razliku od Vrankića, koristio uglavnom arhiv Franjevačke provincije Bosne Srebrene. Kao što je već rečeno Luka Đaković ove se teme dotiče u onom opsegu u kojem je ona bila prisutna u Stadlerovim prijedlozima o katoličkoj autonomiji u Bosni i Hercegovini, poglavito u svom radu "Nastojanje nadbiskupa Stadlera oko stjecanja crkvene autonomije u Bosni i Hercegovini".

Ovaj rad na temelju nekorištenih izvora te korištenih, u gore navedenoj literaturi dajući im opširniju interpretaciju, kao i na temelju gore navedene literature nastoji dati temeljitiji uvid u tematiku te jasnije osvijetliti ulogu svih aktera u slučaju, na osobit način djelovanje nadbiskupa Stadlera koji je bio glavni inicijator i promotor uvođenja kongrue. Rad se ograničava na razdoblje od 1882. do 1910. jer, prema autorovu mišljenju, nakon što je Sveta Stolica sebi pridržala ovo pitanje, uloga nadbiskupa Stadlera u smislu i opsegu kakva je do tada bila, tim je jednostavno prestala.

\section{Prvi Stadlerovi pokušaji oko uređenja kongrue}

Prvi pokušaj nadbiskupa Stadlera da se uredi kongrua, odnosno dolično uzdržavanje župnika, dogodio se neposredno nakon njegova ustoličenja krajem siječnja 1882., a drugi godinu dana poslije, krajem siječnja 1883. Namjera mu je bila doznati od župnika količinu i vrstu župnih prihoda kako bi o tome mogao obavijestiti Zemaljsku vladu i poduzeti potrebne korake da se uredi prikladno uzdržavanje župnika. U dopisu od 30. siječnja 1883. kojega je uputio franjevačkoj upravi u Sarajevu naveo je da je ovo pitanje potrebno urediti kako se vjernici ne bi mogli tužiti "da svećenstvo traži ono što mu po pravu ne ide, a niti da se svećenstvo ne tuži, da mu se ne daje dovoljno za pristojno uzdržavanje". 4 Ni od jednoga ni od drugoga pokušaja nije bilo ništa, jer župnici franjevci nisu reagirali na njegove molbe. ${ }^{5}$

Ponovni pokušaj uslijedio je u rujnu 1885. Nadbiskup je preko dekana pozvao župnike da na ordinarijat "upute molbe Zemaljskoj vladi u Sarajevu da zatraži od carske i kraljevske vlade da ona propiše koliko bi svaki vjernik trebao prinositi godišnje svome župniku". ${ }^{6} \mathrm{Na}$

4 Velimir Blažević, Bosanski franjevci i nadbiskup dr. Josip Stadler, Svjetlo riječi, Sarajevo, 2000., str. 99.

5 Petar Vrankić, Religion und Politik in Bosnien und der Herzegowina (18781918), Schöningh, Paderborn - München - Wien - Zürich, 1998., str. 689-690; V. Blažević, Bosanski franjevci, str. 98-99.

6 P. VRankić, Religion und Politik, str. 690; V. BlažEvić, Bosanski franjevci, str. 100. 
Milenko Krešić - Nastojanja nadbiskupa Stadlera oko uvođenja kongrue...

nadbiskupovu okružnicu reagirao je provincijal bosanske franjevačke provincije fra Antun Ćurić. On je 1. studenoga 1885. dekanima i župnicima franjevcima zabranio da odgovore nadbiskupu. Pohvalio je nadbiskupovu namjeru da se pobrine za dolično uzdržavanje dušobrižnika ali im je napomenuo da su oni franjevci i da su u svemu osim "in cura animarum" - "u skrbi za duše" podložni redovničkim poglavarima te da je samo redovnička uprava nadležna o toj stvari raspravljati s mjerodavnom crkvenom vlašću. Provincijal je također dao do znanja franjevcima koji su se nalazili na župama da bez obzira, ako ordinarijat ili vlada odrede što su vjernici dužni davati svojim župnicima, oni se time ne namjeravaju služiti nego će se držati stare prakse. Prema provincijalovu mišljenju oni se tim načinom ne će služiti jer će to ne samo umanjiti "čast, poštenje i povjerenje puka prema redovnicima" nego i posve oboriti. ${ }^{7}$

Stadler je pitanje kongrue ponovo pokrenuo 1891. godine. Nadbiskup je pisao župnicima da dostave "izvješća o prihodima koje dobivaju i koliko bi trebalo da dobivaju na svojoj župi". ${ }^{8}$ Nadbiskupovo pismo razmatrano je na provincijskom kapitulu Bosne Srebrene 15. travnja 1891. na kojem je zaključeno da se o zavođenju obvezatnih prihoda vjernika s nadbiskupom ne može razgovarati bez pristanka generala reda. ${ }^{9}$ Provincijal fra Andrija Buzuk obavijestio je 20. siječnja 1892. dekane da mogu poslati ordinarijatu izvješća o prihodima na župama ali da ne mogu davati prijedloge za uvođenje kongrue, napominjući im da pravila reda zahtijevaju da se mora živjeti od dobrovoljnih priloga vjernika i da će tako ostati, i ako bi se uvela župna kongrua. ${ }^{10}$

Nadbiskup Stadler ponovo se uključio u pitanje kongrue 1893. godine, kada se pokrenulo pitanje patronata vlade nad župama u Bosni i Hercegovini. Državni tajnik Svete Stolice kardinal Mariano Rampolla tražio je o tome mišljenje nadbiskupa Stadlera i biskupâ sufraganâ Buconjića i Markovića. Kako se vidi iz Stadlerova pisma Buconjiću i Markoviću, on je bio mišljenja da bi umjesto patronata bilo prikladnije riješiti pitanje kongrue. Patronat je za Stadlera bio neprihvatljiv jer bi

7 P. VRankić, Religion und Politik, str. 690; V. BlažEvić, Bosanski franjevci, str. 100-101. Dio provincijalova pisma donosi Blažević na spomenutim stranicama u bilješki 353.

8 V. BlažEvić, Bosanski franjevci, str. 102.

9 V. BLAŽEvić, Bosanski franjevci, str. 102.

10 P. VRankiĆ, Religion und Politik, str. 692; V. BlažEviĆ, Bosanski franjevci, str. 102-103. 
se vlada, kao što se vidi na primjeru Hrvatske, u namještanju župnika vodila isključivo političkim interesima, zanemarujući one crkvene. Predlagao je biskupima sufraganima da se kongrua uredi tako da župnici dobivaju i dalje "u naravi" od naroda ono što inače dobivaju i da im se to zajamči te da povrh toga dobivaju "stalnu potporu" od vlade za uzdržavanje, veću ili manju, ovisno o mjestu i troškovima. ${ }^{11}$ Biskup Buconjić mu je odgovorio da je on što se tiče kongrue istoga mišljenja. Što se tiče patronata generalno je bio protiv. Međutim, u slučajevima "u kojima se primanja svećenika ne mogu drugačije providiti", kao što su mjesta gdje su rijetki katolici raspršeni među nekatolicima, moglo bi se dopustiti. ${ }^{12}$ Biskup Marković bio je i protiv patronata i kongrue. Što se tiče kongrue, odnosno uzdržavanja župnika, smatrao je da treba ostati način kakav je do tada bio u uporabi. ${ }^{13}$ Dobivši odgovore biskupa Buconjića i Markovića nije odmah odgovarao kard. Rampolli nego je najprije, bez obzira na negativan odgovor biskupa Markovića, pokušao stupiti u doticaj s vladom kako bi ona pomogla oko uvođenja i uređenja kongrue. ${ }^{14}$ Stadlerovo pismo u pregledanim arhivskim fondovima Zemaljske vlade i Zajedničkog ministarstva financija nije pronađeno, ali u jednom kasnijem pismu kard. Rampolli Stadler piše da je vladi predložio kako bi trebalo odrediti "neki dio" bez kojega svećenik u dotičnoj župi ne može pristojno živjeti. Župe bi, prema Stadlerovu prijedlogu, trebalo podijeliti u tri razreda tako da župnici župa iz prvoga razreda primaju 1200 for.(inti), iz drugoga 800 for. i iz trećega

11 Stadler Markoviću, 14. 10. 1893., Arhiv Banjolučke biskupije (ABB), VI., 1884.1918., 354/1893; Stadler Buconjiću, 16. 10. 1893., Arhiv Mostarsko-duvanjske biskupije (AMDB), 324/1893.

12 Buconjić Stadleru, 16. 12. 1893., Archivio Apostolico Vaticano (AAV), Archivio della Congregazione degli Affari Ecclesiastici Straordinarii (AA. EE. SS.), Austria, Pos. 660, Fasc. 299, f. 25rv. "Interim, fateor me idem opinari ac Exell. Vestram circa congruam nostris parochis providendam independenter a jure patronatus Gubernii", f. 25r.

13 Marković Stadleru, 29. 10. 1893., AAV, AA. EE. SS., Austria, Pos. 660, Fasc. 299, f. 23r-24r. "Quod spectat ad institutionem et coordinationem congrua cleri curati in Bosnia Hercegovina qua Illustritas V. in supra fata epistola meminit et observat, intime sum persuasionis istius: nihil innovandum, nihil recedendum a consuetidine et praxi hodierna plusquam integro saecolo, nec sine sufficientis decentis sostentationis cleri ejusque utilitate confirmata", f. 23v.

14 "Quae responsa nolui statim ad Eminentiam Vestram mittere, eo quod ad gubernium nostrum litteras supplices misi, ut juvaret nos in disponenda et ordinanda congrua". Stadler Rampolli, 27. 11. 1894., AAV, AA. EE. SS., Austria, Pos. 660, Fasc. 299, f. 20r. 
600 for. ${ }^{15}$ Župnik, koji u svojoj župi prima manje nego što je određeno prema pojedinom razredu, trebao bi ostatak do određene količine primati od vlade. ${ }^{16}$ Vlada na njegov dopis uopće nije reagirala, iako je, kako piše, više puta od nje tražio odgovor. Ne dobivši odgovor vlade odlučio je odgovoriti kard. Rampolli na njegov upit iz rujna 1893. o prikladnosti patronata. Kako se vidi iz odgovora, Stadler je bio protiv patronata kakav je u Austro-Ugarskoj Monarhiji, međutim u krajnjoj liniji ipak bi na nj pristao ali da ga Sveta Stolica dogovori s carem jer, kako piše, "ovako ne može dalje opstati, jer mnogi župnici jedva mogu živjeti". ${ }^{17}$ Prikladnijim rješenjem smatrao je uređenje kongrue te je zamolio kardinala državnoga tajnika da se preko apostolskog nuncija u Beču sve pokuša kako bi se uredila kongrua prema njegovu prijedlogu Zemaljskoj vladi u Sarajevu. ${ }^{18}$

Stadler je pitanje kongrue ponovo postavio na "pozornicu" 1901. godine. Najavljujući kard. Rampolli 8. studenog 1901. da bi se njih trojica biskupa trebala sastati na jedan provincijalni koncil u Banjoj Luci, "ako Sveta Stolica to dopusti", zamolio ga je da se zauzme da Sveta Stolica potakne sklapanje konkordata s Monarhijom za Bosnu i Hercegovinu kojim bi se riješila mnoga goruća pitanja Crkve u Bosni. Jedno od tih gorućih pitanja bila je i kongrua. Stadler je ponovo predložio da se župe podijele u tri razreda te da župnici, ovisno o razredu kojem pripadaju, dobivaju plaću: 1000 kr.(una), 1600 kr. i 2000 kr. jer, kako piše, zbog siromaštva naroda župnici žive oskudno. ${ }^{19}$

15 Kao ilustracija može poslužiti podatak: Stadler je 1890. kupio za ubožnicu u Medenici ulici tri krave koje je platio 300 for. Arhiv SLužaVki MALOG Isusa, ZAGREBAČKA PROVINCIJA, Knjiga računa: 1890.-1899., Izdatak 1890., br. 42 i 43. Dakle, iz ovoga je razvidno kako je župnik na maloj župi, prema Stadlerovu prijedlogu, za svoja godišnja primanja mogao kupiti šest krava.

16 Stadler Rampolli, 27. 11. 1894., AAV, AA. EE. SS., Austria, Pos. 660, Fasc. 299, f. $20 \mathrm{v}$.

17 Stadler Rampolli, 27. 11. 1894., AAV, AA. EE. SS., Austria, Pos. 660, Fasc. 299, f. 21r. "Certum enim est, sic non posse diu permanere, quum multi parochi vix vivere possint", f. $21 \mathrm{r}$.

18 "Omnia facere mediante Nuntio Apostolico Vienensi, quatenus congruam juxta meam propositionem factam gubernio Bosnensi regulatur." Stadler Rampolli, 27. 11. 1894., AAV, AA. EE. SS., Austria, Pos. 660, Fasc. 299, f. 21 r.

19 "Biosognerebbe pure determinare una congrua ai paroci dividendo li in tre parti, quanto al salario: di 1.000 corone, di 1.600 cor. e di 2.000 cor. poichè la popolazione è povera e i paroci vivono a stento." Stadler Rampolli, 8. 11. 1901., AAV, AA. EE. SS., Austria, Pos. 880, Fasc. 392, f. 71v. Citat se također nalazi u: P. VRAnkić, Religion und Politik, str. 692, bilješka 5. 


\section{Pokušaj rješenja u kontekstu "katoličke autonomije"}

Nakon što su bosanskohercegovački pravoslavci kroz prosvjetnoškolsku autonomiju uredili položaj Pravoslavne crkve u BiH, te ujedno time i pitanje uzdržavanja klera, nadbiskup Stadler je ponovo pokrenuo ovo pitanje s katoličke strane u kontekstu rješavanja cjelokupna položaja Katoličke Crkve u BiH. ${ }^{20}$ Jedan od glavnih razloga koji je potaknuo Stadlera na ovaj korak, osim navedene zgodne prilike, sigurno je bio i taj što je s vremenom sve više i više svjetovnih svećenika preuzimalo župe koje su redovito imale manji broj vjernika od župa koje su opsluživali franjevci pa tako i manja primanja s kojima su se jedva mogli uzdržavati.

Prijedlog kako bi trebalo urediti kongruu zajedno s pravoslavnim statutom poslao je početkom listopada 1905. biskupima Markoviću i Buconjiću, bosanskom franjevačkom provincijalu te dekanima u Vrhbosanskoj nadbiskupiji i župniku sarajevskom. ${ }^{21}$ Kako se vidi iz pisma biskupu Markoviću, Stadler je neposredno prije pisanja ovoga pisma razgovarao sa zajedničkim ministrom financija Istvánom Buriánom. Jedna od glavnih tema njihova razgovora bila je kongrua. Stadler je predložio ministru da bi župnici na manjim župama primali godišnje 800 for., srednjim 1000 for., a na većim 1200 for. Ministar se tomu, kako piše, nije protivio pa su se složili da se prouči statut srpsko-pravoslavne autonomije te mu se potom podnese prijedlog. ${ }^{22}$ Kao što je već rečeno, Stadler je sačinio prijedlog te ga poslao na navedene adrese. Što se tiče kongrue predložio je da se, ako bi se sav bir (davanja u naturi) dokinuo osim štolarine (prihoda koji svećenici dobivaju od župljana prilikom podjele sakramenata ili sakramentala), župnicima na manjim župama daje godišnje 800 (900) for., na srednjim župama 1100 (1200) for., na najvećim župama 1200

20 O glavnim odredbama srpsko-pravoslavnog statuta o autonomiji pogledati: P. VRANKIĆ, Religion und Politik, str. 291-295.

21 Arhiv Vrhbosanske nadbiskupije (AVN), prot., 1027/1905. Pismo biskupu Markoviću iz kojega će se crpiti sadržaj Stadlerova pisma. Stadler Markoviću, 3. 10. 1905., ABB, VI., 1884.-1918., 647/1905.

22 "Glavna točka našeg razgovora bješe uredjenje svećeničke kongrue. Ja sam naime predložio, neka bi župnici na najmanji župah godimice dobivali po 800 for., na srednjih po 1.000 for., a na najvećih po 1.200 for. On se tomu predlogu nije otimao. No budući da bi trebalo još puno toga urediti, onda se o tom složismo, da bi najbolje bilo, da proučimo statut izdan za hrišćane, pa da mu načinimo predlog." Stadler Markoviću, 3. 10. 1905., ABB, VI., 1884.-1918., 647/1905. 
Milenko Krešić - Nastojanja nadbiskupa Stadlera oko uvođenja kongrue...

(1500) for. te kapelanima 600 for. ${ }^{23}$ Biskup Buconjić odgovorio je 4. studenoga 1905. da je prijedlog dao konzistorijalcima "na pretres" te da se s prijedlogom uglavnom slaže. ${ }^{24}$ Uprava franjevačke provincije Bosne Srebrene, odnosno Definitorij o nadbiskupovu prijedlogu raspravljao je 14. prosinca 1905. i načelno s tri glasa za i dva protiv pristao da se s nadbiskupom uđe u razgovor o uvođenju kongrue ali pod sljedećim uvjetima: 1 . da biskupi metropolije prihvate načelan prijedlog da se franjevački kandidati uzdržavaju sredstvima koja su na raspolaganju i svjetovnim kandidatima; 2 . da u pregovorima o kongrui sa Zemaljskom vladom sudjeluje i provincijal; 3. da u uređenju i provođenju kongrue provincija sudjeluje ravnopravno $s$ ordinarijatom prema broju svojih članova. ${ }^{25}$ Odgovor biskupa Markovića na Stadlerovo pismo s početka listopada u protokolima Vrhbosanske i Banjolučke biskupije nije zabilježen. Međutim, može se pretpostaviti da je postojao nekakav usmeni odgovor što bi se moglo zaključiti iz daljnjih koraka biskupa Markovića iz kojih se vidi da je bio za uvođenje kongrue. Naime, kada je Stadler dobio odgovor franjevačke uprave, proslijedio ga je biskupima Markoviću i Buconjiću zatraživši od njih mišljenje. On je smatrao da se dvije posljednje točke protive kanonskom pravu. ${ }^{26}$ Biskup Marković mu je odgovorio, što se tiče prve točke, da je konvencijom između Austro-Ugarske Monarhije i Svete Stolice i papinom bulom određeno kako će se uzdržavati kandidati svjetovnoga klera te da biskupi Bosne i Hercegovine ne mogu "po sebi u tome što mienjati i prikrajati" te da se nitko "ne protivi da i redovnička franjevačka mladež u Bosni i Hercegovini isto zadobije; te stoga dotičnom franjevačkom starješinstvu nitko ne bi zamjerao, kada bi to na vrhovnom odlučujućem mjestu i postigao, pače bi se svatko i radovao". ${ }^{27} \mathrm{U}$ odnosu na dvije posljednje točke i Marković je bio mišljenja da "se načelno ta tražbina ne može prihvatiti, jer se ne

23 Stadler Markoviću, 3. 10. 1905., ABB, VI., 1884.-1918., 647/1905. Podatak se također nalazi u: P. VRankić, Religion und Politik, str. 693.

24 "Vaše predloge dao sam bio na pretres mojim konsistorijalcima, kao i 'Štatut' za hrišćane uredjen pak smo stoga malo zakasnili. S Vašim predlozima slažemo se i mi uglavnom." Buconjić Stadleru, 4. 11. 1905., AVN, 1124/1905.

25 Prijedlog franjevačke uprave Stadler je poslao biskupu Markoviću, 4. 1. 1906., ABB, VI., 1884.-1918., 9/1905.; P. VRankić, Religion und Politik, str. 693, osobito bilješka 2; V. BLAžEvić, Bosanski franjevci, str. 103-104.

26 AVN, prot., 8/1906.; Stadler Markoviću, 4. 1. 1906., ABB, VI., 1884.-1918., 9/1906.

27 Marković Stadleru, 14. 1. 1906., ABB, VI., 1884.-1918., 35/1906. 
podudara s crkvenim pravom niti s crkvenom tradicijom". ${ }^{28}$ Odgovor biskupa Buconjića u protokolu Vrhbosanske nadbiskupije nije pronađen. Odbijanje franjevačkoga prijedloga vjerojatno je bio razlog pa je Definitorij Provincije na predkapitularnoj sjednici 2. travnja 1906. odlučio da se pitanje kongrue ne stavlja na dnevni red. ${ }^{29}$

Nakon spomenute korespondencije i događanja, nadbiskup Stadler je 20. siječnja 1907. podnio Zemaljskoj vladi prijedlog za "katoličku autonomiju" po uzoru na srpsko-pravoslavnu. Prijedlog je, kako piše nadbiskup, podnesen ne samo u ime Vrhbosanske nadbiskupije, nego i u ime ostalih biskupa i u sporazumu s franjevačkim provincijalima. ${ }^{30}$ Suglasje s biskupima sufraganima, kao što je već izneseno, postojalo je, međutim ostaje upitno je li postojalo suglasje s franjevačkim provincijalima. U pisanoj korespondenciji nema mu nikakva traga. ${ }^{31}$

Jedna od točaka u prijedlogu o autonomiji koji je Stadler podastro vladi bilo je uređenje kongrue. Naime, nadbiskup je predložio da bi bilo najbolje da se zadrži bir "uobičajen prošlošću i narodnim običajem", s tim da bi vlada preko svojih službenika bila na pripomoć župnicima u ubiranju bira u slučajevima kada netko ne želi dobrovoljno dati svoj prilog. Osim toga, piše nadbiskup, kako ima "slabih župa, kakvih je ve-

28 Marković Stadleru, 14. 1. 1906., ABB, VI., 1884.-1918., 35/1906.

29 V. BlažEvić, Bosanski franjevci, str. 104.

30 "[...], to se smjerno potpisani kako u ime nadbiskupije Vrhbosanske, tako i u ime svih ostalih biskupija, mostarske, banjalučke i trebinjske, sporazumno s obadva franjevačka provincijala obraća na tu visoku Vladu". Stadler Vladi, 20. 1. 1907., ABiH, ZajedničKo ministarstvo financija (ZMF), Präesidum (Präs.), 160/1907. Tekst prijedloga objavljen je s komentarima autora u: LUKA ĐA Ković, "Nastojanje nadbiskupa Stadlera oko stjecanja crkvene autonomije u Bosni i Hercegovini", (ćir.), u: Prilozi instituta za istoriju, 18, Sarajevo, 1981. str. 235-236. Pogledati također: LuKA ĐA Ković, Političke organizacije bosanskohercegovačkih katolika Hrvata (I. dio: Do otvaranja Sabora 1910.), Globus, Zagreb, 1985., str. 126; P. VRANKIĆ, Religion und Politik, str. 693-694; MARKo Karamatić, Franjevci Bosne Srebrene u vrijeme austrougarske uprave 1878. 1914., Svjetlo riječi, Sarajevo, 1992., str. 171-172; V. BLAŽEvić, Bosanski franjevci, str. 104-105.

31 Blažević i Vrankić mišljena su da dogovora nije bilo. "Nadbiskupski ordinarijat nije nastavio pregovaranje s upravom Provincije o kongrui, ali je 1907. nastupio kod Zemaljske vlade samostalno is modificiranim prijedlogom." V. BLAžEvić, Bosanski franjevci, str. 104. Sličnog je stajališta i Vrankić: "Stadler war durch da zögernde Verhalten der Franziskaneroberen tief gekränkt und versuchte in direkten Verhandlungen über die katholische Autonomie mit der Landesregierung auch die allgemeine Frage der Dotierung des Seelsorgeklerus in Bosnien und Herzegowina zu klären." P. VRANkić, Religion und Politik, str. 693. 
ćina po Bosni-Hercegovini", bilo bi potrebno da se župnicima na tim župama povrh bira daje pripomoć od 1000 do 2000 kruna. Kako bi se i onim svećenicima koji nemaju nikakva bira, osobito kapelanima, osiguralo dolično uzdržavanje, predložio je da se "katoličkom dušobrižništvu dade $10 \%$ od poreza i ta svota da se među biskupije podijeli prema broju pučanstva". ${ }^{32}$ Zemaljska vlada, koja je također smatrala potrebnim urediti ovo pitanje, Stadlerov prijedlog nije mogla prihvatiti ponajviše iz razloga jer se smatralo da bi to bilo preveliko opterećenje za katoličko pučanstvo. Prema njezinu mišljenju najprikladnije bi bilo kada bi se katolički episkopat mogao složiti da se umjesto dosadašnjega bira uvede $10 \%$ kultni prirez, s tim da se to može provesti i u župama koje pripadaju franjevcima. ${ }^{33}$ Kako vlada nije prihvatila nadbiskupov prijedlog o uređenju autonomnog položaja Katoličke Crkve, tako nije prihvatila ni prijedlog o uređenju kongrue.

Ponovo se o uređenju kongrue počelo govoriti u lipnju 1909. Kako su muslimani bili na pragu rješenja svojega statusa kroz vakufskomearifijsku autonomiju, nadbiskup je ponovo počeo raditi na rješavanju statusa Katoličke Crkve. Što se tiče kongrue, izradio je detaljan prijedlog koji se trebao uputiti Zajedničkom ministarstvu financija. Prijedlog je osim svećenika u pastoralu uključivao također i svećenike koji bi zbog bolesti, privremeno ili trajno, bili onesposobljeni za pastoralnu službu. Prema nadbiskupovu prijedlogu s uvođenjem kongrue prestalo bi ubiranje bira. Župe bi bile podijeljene u četiri razreda prema broju vjernika. Župnici bi, ovisno o razredu župe kojom upravljaju, dobivali godišnju plaću od 1200 do 3600 kr., s time da bi im se šest puta kroz petogodišnju službu plaća povećavala za po 200 kr. Kapelani bi dobivali godišnju plaću po 1200 kr., a bolesni svećenici nesposobni za pastoralnu službu, ovisno o godinama provedenim u pastoralu, 800, odnosno $1200 \mathrm{kr}$. pa naviše. Kako bi Ministarstvo znalo koliko će podići prirez na svaku župu, dotični bi župnici trebali "točno i vjerno" dostaviti koliko godišnje primaju od svojih župljana i od zemljišnih prihoda ako ih župa posjeduje. ${ }^{34}$ Prije upućivanja

32 Stadler Zemaljskoj vladi, 20. 1. 1907., ABiH, ZMF, Präs., 160/1907.; ABiH, ZVS, Reservierte (Res.), 5352/1907.; L. ĐAKOVIĆ, "Nastojanje nadbiskupa Stadlera", str. 235-236; P. VRankić, Religion und Politik, str. 694.

33 Winzor Ministarstvu financija, 27. 9. 1907., ABiH, ZMF, Präs., 1123/1907.; L. ĐAкоvić, "Nastojanje nadbiskupa Stadlera", str. 240; P. VRANkić, Religion und Politik, str. 694.

34 Stadler Markoviću, 18. 6. 1909., ABB, VI., 1884.-1918., 389/1909.; Stadler Buconjiću, 18. 6. 1909., AMDB, 389/1909. Stadlerov prijedlog se također nalazi 
Ministarstvu, Stadler je prijedlog poslao 18. lipnja 1909. biskupima u Mostaru i Banjoj Luci, te upravi bosanske franjevačke provincije. ${ }^{35}$

Biskup Marković odobrio je njegov projekt. Zahvalio mu je što se odlučio na uređenje kongrue "neka bi jednoć tužaljke prestale od strane župnika, a i župljani nemarni prisilili se i obavezali na svoju dužnost, za uzdržavanje svoga župnika". ${ }^{36}$ Biskup Buconjić je bio protiv. Smatrao je da prijedlog nije povoljan za svećenike jer prema njegovu mišljenju postaju "državni službenici što je vrlo opasno za nas". Smatrao je također da kategorizacija župa, saslušavši "neke svećenike osobito svjetovne" nije dobra, nego da bi se primanja trebala rasporediti "prema službi kako koji služi i teškoći službe". ${ }^{37}$ Bosanski franjevački provincijal fra Franjo Komandanović odgovorio je na Stadlerov upit 20. srpnja 1909. da ne može ništa odgovoriti "bez kongresa sve provincije" koji se trebao održati prvih dana kolovoza $1909 .{ }^{38} \mathrm{Kroz}$ ovo vrijeme, od 18. lipnja do 20. srpnja 1909., dogodile su se dvije bitne stvari. Provincijal Komandanović dobivši Stadlerov upit od 18. lipnja pisao je 3. srpnja generalu reda, iznijevši mu poteškoće koje bi zadesile franjevce uvođenjem kongrue i pitao ga za savjet kako postupati u ovim okolnostima. Naime, kako provincijal piše, uvođenjem kongrue došla bi u opasnost opstojnost njihovih samostana i odgojnih zavoda kao i redovnička disciplina, poslušnost župnika koji bi uvođenjem kongrue uvelike ovisili o nadbiskupu. ${ }^{39}$ General mu je odgovorio 12. srpnja da kongrua nije u skladu s "Regulom" te se izja-

u talijanskom prijevodu u: AAV, AA. EE. SS., Austria, Pos. 1036, Fasc. 442, f. 38r-40r. O njemu također: P. VRANKIĆ, Religion und Politik, str. 695.

35 Stadler Markoviću, 18. 6. 1909., ABB, VI., 1884.-1918., 389/1909.; Stadler Buconjiću, 18. 6. 1908., AMDB, 198/1909.; Upravi bosanske franjevačke provincije, AVN, 720/1909.

36 Marković Stadleru, 24. 6. 1909., AVN, 738/1909.

37 Buconjić Stadleru, 6. 7. 1909., AVN, 796/1909.

38 Komandanović Ordinarijatu, 20. 7. 1909., AVN, 880/1909. O Komandanovićevu odgovoru također: P. VRankić, Religion und Politik, str. 695; V. BLAŽEvić, Bosanski franjevci, str. 105.

39 "Si vero congrua instituetur, tunc proventus parochorum certi reddentur,... ut parochi absolute nulla superflua habituri sint, quia etiam ipsi parochi, si modice vixerint, vix honestam sustentationem ex provendibus congruae, habere poterunt, atque ita convectus nostri et consequenter etiam studia nostra privabuntur primariis suis proventibus et necessario interibunt. Praetera, non parum pertimescenda est, relaxatio disciplinae et insubordinatio religiosorum in parochiis viventium, quia omnis autonomia et tota res congrae in manibus Archiepiscopi erit, ab eiusdemque arbitrio etiam poenae et mulctae 
snio za stari običaj da se franjevci na župama uzdržavaju dobrovoljnim prilozima vjernika. ${ }^{40}$ Negdje u isto vrijeme, nadbiskup Stadler je uz odobrenje biskupa Markovića zatražio od župnika da ordinarijatu dostave točno koliko primaju od župljana ili župe obavijestivši o tome također i upravu provincije. ${ }^{41}$ Poslije toga je do ordinarijata došla vijest da je uprava provincije izdala "tajnu naredbu" franjevcima župnicima da ordinarijatu ne dostavljaju zatražene podatke. Ordinarijat je od uprave provincije zatražio da "dotičnu tajnu naredbu opozove" kako se ne bi "morao poslužiti pravom svoje jurisdikcije, te je dotične dušobrižnike sub poena suspensionis" ponovo pozvao da dostave tražene podatke. ${ }^{42} \mathrm{Na}$ dopis ordinarijata odgovorio je provincijal fra Franjo Komandanović spočitavajući ordinarijatu da je "nasjeo", jer provincijalat nikakvu tajnu naredbu nije izdao, nego je izdao službeni dopis samostanima a preko samostana župnicima da se franjevci ne smiju izjašnjavati za kongruu do "kongresa provincije". ${ }^{33}$ Je li postojala kakva "tajna naredba"? Vrankić i Blažević pišu da jest. Vrankić se oslanja na sažetak Komandanovićeva pisma u Protokolu Arhiva franjevačke provincije Bosne Srebrene a Blažević na dopis ordinarijata. ${ }^{44}$ Pregledani arhivski spisi, kako oni u ordinarijatu, tako i u provinciji, odnosno u Protokolu, nude jedno te isto Kotromanovićevo pismo. ${ }^{45} \mathrm{Je}$ li ova "Kotromanovićeva naredba" slovila kao tajna ili nije, nije moguće utvrditi. Na spomenuti dopis provincijala Komandanovića u pregledanim arhivskim spisima od ordinarijata nema nikakve reakcije. Međutim, ono što je vidljivo iz pregledanih arhivskih spisa, nisu svi franjevački župnici postupili po naredbi provincijalata. Tako je npr. župnik iz Fojnice fra Ivan Vujičić obavijestio vrhbosanski ordinarijat

parochorum pendebunt." Komandanović Schuleru, 3. 7. 1909., Curia GeneRale dei Frati Minori (CGFM), Roma, Bosnia SK 161, f. 422r-423v.

40 Schuler Kotromanoviću, 12. 7. 1909., Arhiv franjevačke provincije u Sarajevu (AFPS), Protocollum VII, str. 197; P. VRAnkić, Religion und Politik, str. 695696; V. BlažEvić, Bosanski franjevci, str. 105-106.

41 Stadler Provincijalatu, 23. 7. 1909., AVN, 880/1909.

42 Stadler Provincijalatu, 23. 7. 1909., AVN, 880/1909.

43 Komandanović Ordinarijatu, 25. 7. 1909., AVN, 905/1909.

44 P. VRankić, Religion und Politik, str. 695, bilješka 6. Blažević piše da je provincijal fra Alojzije Mišić u međuvremenu izdao spomenutu tajnu naredbu oslanjajući se na dopis ordinarijata od 23. srpnja 1909. Činjenično stanje je da tada nije bio provincijal fra Alojzije Mišić nego fra Franjo Komandanović tako da Mišić spomenutu naredbu nije mogao izdati. V. BLAžEVIĆ, Bosanski franjevci, str. 106.

45 Komandanović Ordinarijatu, 25. 7. 1909., AVN, 905/1909.; Sažetak Komandanovićeva pisma: AFPS, Protocollum VII, str. 197. 
da na prijedlog "toga i banjalučkoga ordinarijata" ne može odgovoriti jer je njima kao redovnicima strogo zabranjeno "da o tomu što radimo, jer je to stvar starešinstva našega". Za razliku od njega upravitelj župe plehanske fra Ante Stanić izvijestio je ordinarijat da župnik plehanski što u novcu što u naravi računajući također i štolarinu od župljana godišnje prima oko $5000 \mathrm{kr}^{46}$

O kongrui se raspravljalo na predkapitularnom zasjedanju provincijalne uprave 8. kolovoza 1909. u Gučoj Gori. Na sjednici je pročitano generalovo pismo u kojem se izjasnio protiv uvođenja kongrue na župama koje opslužuju franjevci. Većina sudionika također se izjasnila protiv. O donesenoj odluci novi provincijal fra Alojzije Mišić obavijestio je nadbiskupa Stadlera 19. kolovoza 1909. Najprije ga je upoznao s generalovim stajalištem te mu priopćio odluku provincije: "Kongrua kakva se predlaže nije za Bosnu shodna" i to iz sljedećih razloga: 1. papa Pio X. preporučio je u sličnom slučaju biskupima u Francuskoj da bi najbolje bilo da se svećenici uzdržavaju od milostinje i milodara; 2 . direktnim davanjima vjernika najbolje se osigurava sloboda svećeničkog djelovanja; 3. s dosadašnjim načinom davanja osigurava se prisnost između svećenika i vjernika dok bi drugim načinom, odnosno kako piše "u obliku namire" izgledali kao najamnici i 4. "Dušmani bi katoličke vjere i crkve" to iskoristili te bi bunili narod govoreći mu da plaća poreze za "popove i fratre": "Fratri i popovi hoće za sebe, briga njih što ti nemaš ovo ili ono". ${ }^{47}$ Sabrana braća su ipak bila mišljenja da se ne može ostati pri starom te su "u ime poboljšanja sadašnjeg stanja i davanja od strane naroda predložili" sljedeće: 1. neka svaki župnik popiše što prema starom običaju "svaka kuća ili familija mora davati", da se taj popis potvrdi od ordinarijata i vlade te da niže oblasti poput kotarskih budu "na ruku" župniku "za bir nemarna davaoca silom, kad nije htjeo milom, upiti: 'moraš dati"'; 2 . da se dogovorom ordinarijata i vlade odredi da svećenici koji oskudno žive dobiju iz "zemaljskih sredstava" povećanu potporu kako bi pristojno živjeli i 3. da se naseljenicima i onima koji su s njima jednaki te iz raznih razloga ništa ne daju za uzdržavanje svećenika a ipak traže svećeničke usluge nametne porez od $10 \%$ u ime kongrue. ${ }^{48}$

46 Vujičić Ordinarijatu, 20. 7. 1909., AVN, 900/1909.; Stanić Ordinarijatu, 1. 8. 1909., AVN, 994/1909.

47 Mišić Stadleru, 19. 8. 1909., AFPS, Protocollum VII, str. 221-222. Vidi također: V. Blažević, Bosanski franjevci, str. 106-107.

48 Mišić Stadleru, 19. 8. 1909., AFPS, Protocollum VII, str. 222. Vidi također: V. BlAŽEvić, Bosanski franjevci, str. 107. 
Milenko Krešić - Nastojanja nadbiskupa Stadlera oko uvođenja kongrue...

\section{Pokušaj u dogovoru sa Zemaljskom vladom}

$\mathrm{Na}$ dopis provincijala Mišića nadbiskup Stadler nije odgovarao. Odlučio se obratiti Zemaljskoj vladi i od nje zatražiti mišljenje o svojemu prijedlogu. Zajedno s pomoćnim biskupom Ivanom Šarićem posjetio je civilnog adlatusa Isidora Benka 5. listopada 1909. Prema Benkovu izvješću ministru financija Istvánu Buriánu Stadler je predložio da se problem kongrue riješi slično kao što je riješen kod pravoslavnih Srba, tj. da se umjesto bira uvede $10 \%$ prirez svim vjernicima čiji bi se iznos, s onim što je vlada do sada davala za uzdržavanje katoličkoga kulta, predao crkvenoj upravi u svrhu plaćanja svećenika. Stadler je računao da bi taj iznos mogao iznositi oko $400.000 \mathrm{kr}$. (300.000 od vjerskog prireza i 100.000 iz proračuna) i da bi mogao biti dovoljan za uzdržavanje župnika. Bilo bi potrebno, prema njegovu mišljenju, još $100.000 \mathrm{kr}$. za uzdržavanje kapelana te je pitao civilnog adlatusa Benka bi li se mogao nadati da će vlada tu svotu posebno odobriti. ${ }^{49}$ Na Stadlerove riječi Benko je odgovorio da je vlada spremna poduprijeti rješenje ovoga pitanja ali samo na istim osnovama kao što je dotični problem riješen s pravoslavnima i muslimanima, odnosno da će proračunski novac izdvajati proporcionalno prema brojnosti pojedine vjerske zajednice te da je za državno odobrenje $10 \%$-og vjerskog prireza potrebno da "svi uključeni čimbenici" to traže ili da su barem $\mathrm{s}$ tim suglasni. ${ }^{50}$ Govoreći o svim čimbenicima, Benko je mislio na katoličke vjernike jer je potom, kako piše, dao do znanja nadbiskupu da za zakonsko uvođenje kongrue ne će biti dovoljan samo zahtjev biskupa i klera nego da će vladi trebati dokaz da je katoličko stanovništvo spremno na sebe preuzeti ovo opterećenje. Dao je također do znanja nadbiskupu da ne može računati iz proračuna na dodatnu svotu koju je tražio za kapelane, odnosno da se može računati samo na svotu proporcionalnu broju katoličkih vjernika. ${ }^{51} \mathrm{U}$ nastavku razgovora o mogućemu modus-u procedendi oko uređenja kongrue pokazali su se sljedeći problemi koje je i Stadler, premda nevoljko, morao priznati: 1 . da su franjevci protiv namjeravana uređenja kongrue jer s postojećim načinom bolje prolaze; 2 . da se ne može računati

49 Benkovo izvješće o susretu sa Stadlerom i Šarićem, 6. 10. 1909., ABiH, ZMF, Präs., 1973/1909.; P. VRAnkić, Religion und Politik, str. 696-697.

50 Benkovo izvješće o susretu sa Stadlerom i Šarićem, 6. 10. 1909., ABiH, ZMF, Präs., 1973/1909.; P. VRankić, Religion und Politik, str. 697.

51 Benkovo izvješće o susretu sa Stadlerom i Šarićem, 6. 10. 1909., ABiH, ZMF, Präs., 1973/1909.; P. VRAnkić, Religion und Politik, str. 697. 
s jednoglasjem biskupa jer biskup Buconjić nema odvažnosti glasovati protiv mišljenja franjevaca i 3 . da bi uprave obiju franjevačkih provincija glasovale protiv ovoga projekta. ${ }^{52}$ Što se tiče posljednjega problema, Stadler je napomenuo da redovnička uprava uopće nije kompetentna o tome raspravljati. ${ }^{53}$

Kako Benko prenosi, Stadler je bio uvjeren da će narod s radošću prihvatiti njegov prijedlog jer će, barem u franjevačkim župama, plaćati manje nego što je do sada plaćao. ${ }^{54} \mathrm{Na}$ to $\mathrm{mu}$ je Benko ponudio da učini provjeru, odnosno da preko biskupa i svećenika ispita jedan broj uglednijih župljana po župama "što bi bilo vrlo pogodno za podršku" njegovim nastojanjima. Međutim, kako navodi Benko, Stadler se, premda je i dalje bio uvjeren da narod tako misli, bojao da bi izvješća s franjevačkih župa mogla biti lažirana.${ }^{55}$ Nakon ovoga Benko je zaključio da vlada ne će moći bez jednoglasne odluke biskupa, pristanka franjevaca i župljana kojih se to tiče nametnuti takav zakon. ${ }^{56}$ Predložio je nadbiskupu drugi način, da u saboru, u kojem sjede predstavnici katoličkoga klera i naroda, te muslimanski i srpsko-pravoslavni zastupnici, predloži jedan takav prijedlog zakona. Benko je bio uvjeren da će srpsko-pravoslavni i muslimanski zastupnici, kada čuju da nadbiskup traži nešto što su oni već dobili, zbog osjećaja pravednosti glasovati za taj zakon. Stadler je ovaj prijedlog odbio jer je smatrao neprihvatljivim da o katoličkoj stvari odlučuju predstavnici drugih vjera. ${ }^{57}$

52 Benkovo izvješće o susretu sa Stadlerom i Šarićem, 6. 10. 1909., ABiH, ZMF, Präs., 1973/1909.; P. VRankić, Religion und Politik, str. 697.

53 Benkovo izvješće o susretu sa Stadlerom i Šarićem, 6. 10. 1909., ABiH, ZMF, Präs., 1973/1909.

54 Benkovo izvješće o susretu sa Stadlerom i Šarićem, 6. 10. 1909., ABiH, ZMF, Präs., 1973/1909.

55 "Darauf meinte dr. Stalder, mit einiger Verlegenheit, er wisse ganz bestimmt, dass das Volk so denke, indessen sei dasselbe leicht zu betören und er fürchte mit Grund, dass in den Franziskanerpfarren - selbst wenn er besondere Exmissen in dieselben sende - die wahrhafte Volksmeinung nicht zum Vorschein kommen, sondern durch die Pfarrer gefälscht werden wird." Benkovo izvješće o susretu sa Stadlerom i Šarićem, 6. 10. 1909., ABiH, ZMF, Präs., 1973/1909.

56 Benkovo izvješće o susretu sa Stadlerom i Šarićem, 6. 10. 1909., ABiH, ZMF, Präs., 1973/1909.

57 Benkovo izvješće o susretu sa Stadlerom i Šarićem, 6. 10. 1909., ABiH, ZMF, Präs., 1973/1909. 
Milenko Krešić - Nastojanja nadbiskupa Stadlera oko uvođenja kongrue...

Shvativši da za sada nema načina da se kongrua uvede za sve župe, Benko je biskupima predložio da se ona ograniči na župe dijecezanskoga klera. Biskupi su, kako piše barun, ostali iznenađeni ovim prijedlogom te su ga odmah prihvatili. ${ }^{58}$

Negdje u to vrijeme biskup Marković povukao je svoj pristanak na Stadlerov prijedlog o kongrui. ${ }^{59}$ Bez pristanaka biskupa sufragana i franjevačkih provincijala, potaknut riječima baruna Benka, Stadler se u ovom trenutku odlučio uređenje kongrue ograničiti samo na svjetovne svećenike Vrhbosanske nadbiskupije. Uputio je 22. listopada 1909. okružnicu dijecezanskom kleru svoje nadbiskupije da prigodom nadolazeće svetkovine Svih Svetih "od boljih župljana i kućnih starješina" koji su do sada redovito obavljali svoju dužnost prema župniku dobiju suglasnost da se dotadašnji bir zamjeni 10\%nim vjerskim prirezom. U okružnici je, kako je navedeno u vladinu dopisu, bilo izričito naglašeno da se na sastanke ne pozivaju oni koji do sada nisu davali ništa za uzdržavanje župnika, a to su bili uglavnom doseljenici, ali da će i oni, jednom kad se prirez uvede, biti dužni plaćati kao i ostali. ${ }^{60}$ Dobivene odgovore sa župa Stadler je proslijedio Zemaljskoj vladi 21. studenoga 1909. kao dokaz da vjernici u dijecezanskim župama žele zamjenu dotadašnjeg bira s 10\%nim prirezom. U popratnom pismu naveo je da je poziv bio poslan svim župama u kojima djeluje svjetovni kler te da je odgovore dobio sa svih župa osim onih u Sarajevu, Novom Sarajevu i Goraždu gdje, kako piše, "nema katoličkih seljaka ter se do sada nije davao nikakav pobir". U svim ostalim župama seljaci su "drage volje pristali na taj prijedlog i s veseljem ga pozdravili", osim u Travniku odakle je stigao negativan odgovor. Stadler je $\mathrm{u}$ istom ovom popratnom pismu naznačio Zemaljskoj vladi, da u ostale biskupije nije slan poziv, ali da su i tamo dijecezanski svećenici, saznavši za ovaj plan, "pitali svoj narod, te je tako i iz banjalučke i trebinjske biskupije stiglo više pisa-

58 "Die beide Bischöfe schienen frappirt durch meine Ausfürungen und waren sofort für das vorgeschlagene Auskunftsmittel gewonnen." Benkovo izvješće o susretu sa Stadlerom i Sarićem, 6. 10. 1909., ABiH, ZMF, Präs., 1973/1909.

59 "Essendo in quel tempo scoppiato l'altro dissidio, sopra ricordato, su la questione politica tra i francescani e Monsignor Stadler, questi, prima di fare ulteriori passi presso i detti religiosi, volle conoscere il pensiero del Governo [...]. A questo punto, avendo anche Mons. Markovic ritirata la sua adesione al progetto in parola." AAV, AA. EE. SS., Austria, Pos. 1036, Fasc. 442, f. 8v-9r.

60 Vlada Ministarstvu, 29. 1. 1910., ABiH, ZMF, Präs., 150/1910.; također: P. VRAnkiĆ, Religion und Politik, str. 697. 
nih izjava u gornjem smislu". Na kraju je zamolio vladu da poduzme shodne korake i požuri "ovo goruće pitanje". ${ }^{61}$

U međuvremenu, svakako između Svih Svetih, tj. 1. i 12. studenoga 1909., sastali su se nadbiskup Stadler i bosanski provincijal Mišić. Kako piše provincijal Mišić u pismu upućenu braći franjevcima 12. studenoga 1909. nadbiskup ga je tom prilikom upoznao s rezultatom "ankete" provedene na svjetovnim župama, tj. "narod povjeren njihovoj pastvi mjesto bira prihvatio je listom kongruu", te ga je pitao što o tome misle franjevci? ${ }^{62}$ Provincijal je također braći dao do znanja da je ordinarijat uputio upit vladi: "Bi li htjela Vlada, u župama koje služe svećenici sekul. klera, pobirati od župljana 10\% namet, isplaćivati ga dotičnim svećenicima, a č. oo. franjevcima ostaviti bir?", na što je vlada odgovorila "da će drage volje pobirati od naroda, što se izjavi za kongruu $10 \%$ namet. ${ }^{63}$ Potom im je iznio financijsko stanje provincije, osobito što se tiče samostana i s njima povezanih "uzgojnih zavoda" koji su se do tada uzdržavali od prihoda sa župa te ih pitao hoće li i dalje župe, u slučaju uvođenja kongrue, moći nastaviti doprinositi uzdržavanju samostana i odgojnih zavoda ${ }^{64}$ Većina pitane braće, zapravo svi osim njih pet, izjasnila se protiv uvođenja kongrue. Ova petorica, kako je zapisao fra Petar Ćorković, tajnik i kronolog provincije, izjasnila su se za uvođenje kongrue "ali pod takovim uslovima koji su neispunivi, jer ih nitko - ne nudi". ${ }^{65}$ Zanimljiv je također i osobni fra Petrov komentar koji na vrlo plastičan način ocrtava stajalište franjevačke uprave u odnosu na kongruu: "Moje je mnijenje da se ne bi nitko strašio kongrue, kad bi nam vlada obezbijedila učilišta sa većom subvencijom bar od jedno 50 - 60 hiljada Kruna." ${ }^{66}$

Odgovore sa župa i Stadlerovu molbu od 21. studenoga 1909. službenici Zemaljske vlade pomno su analizirali. Mišljenje vlade o ovom pitanju, s potpisom zemaljskoga poglavara generala Varešanina, po-

61 Stadler Vladi, 21. 11. 1909., ABiH, ZVS, Präs., 2161/1910.

62 Mišić braći franjevcima, 12. 11. 1909., AFPS, Protocollum VII, str. 223.

63 Mišić braći franjevcima, 12. 11. 1909., AFPS, Protocollum VII, str. 223.

64 Mišić braći franjevcima, 12. 11. 1909., AFPS, Protocollum VII, str. 224. Blažević, obrađujući ovo Mišićevo pismo, piše da je provincijal pitao: "Što braća misle ako bi se silom pokušalo uvesti kongruu i na franjevačke župe?" U Mišićevu pismu nema nikakva spomena sili niti se ovakav zaključak iz njega može izvesti. V. BlažEvić, Bosanski franjevci, str. 107.

65 Komentar tajnika i kronologa fra Petra Ćorkovića, AFPS, Protocollum VII, str. 224.

66 Komentar tajnika i kronologa fra Petra Ćorkovića, AFPS, Protocollum VII, str. 224. 
Milenko Krešić - Nastojanja nadbiskupa Stadlera oko uvođenja kongrue...

slano je Zajedničkom ministarstvu financija u Beč 29. siječnja 1910. ${ }^{67}$ Prema vladinoj analizi od 40 župa u Vrhbosanskoj nadbiskupiji, uključujući i Zvornik, 22 seoske župe dale su bezrezervnu podršku zamjeni bira 10\%-nim prirezom, u mješovito gradsko-seoskim župama seosko stanovništvo bilo je također $z a$ dok je gradsko stanovništvo uglavnom bilo protiv. U čisto gradskim župama ispitano je samo stanovništvo župe Travnik koje je bilo protiv a u ostalim gradskim župama: Sarajevo, Novo Sarajevo, Zvornik i Goražde, "koji do sada nisu davali ništa" očito uopće nije pitano. ${ }^{68} \mathrm{Na}$ osnovi ove analize vlada je zaključila da za sada ne postoje potrebni preduvjeti za uvođenje kongrue ali, isto tako, da Katolička Crkva ne može dugoročno u ovom pitanju zaostajati za pravoslavnim i muslimanima te da Stadlerov prijedlog, čak ako bi se za sada morao ograničiti samo na dijecezanske župe Vrhbosanske nadbiskupije, zaslužuju njihovu punu podršku. ${ }^{69}$ Naime, što se tiče seoskoga stanovništva vlada je smatrala da se pisane izjave u najboljem slučaju mogu smatrati dostatnim, ali problem je bilo stanovništvo po gradskim župama. Vlada je bila mišljenja da bi bilo "ispravno i pošteno" da i ono poput seoskoga stanovništva preuzme na sebe obveze plaćanja vjerskog doprinosa što bi mogao biti dobar povod da se i franjevci u dogledno vrijeme pridobiju za kongruu. ${ }^{70}$ Međutim, vlada nije mogla vjerski prirez nametnuti bez neke osnove. Kako za to nije postojao ni državni zakon, ni od države odobren crkveni statut, ni običajno pravo koje bi vezalo gradsko uglavnom doseljeno stanovništvo na plaćanje vjerskoga doprinosa, vlada je bila mišljenja da bi to bilo moguće jedino kad bi se u gradskim i mješovitim župama ustanovio odbor ad hoc koji bi predstavljao sve župljane, koji bi potom donio odluku da se uvede obvezatni vjerski doprinos. ${ }^{71}$ Prije zaključenja ovoga izvješća dijecezanski svećenici Vrhbosanske nadbiskupije podnijeli su vladi neposrednu

67 Varešanin Ministarstvu, 29. 1. 1910., ABiH, ZMF, Präs., 150/1910.; P. VRANKIĆ, Religion und Politik, str. 698.

68 Varešanin Ministarstvu, 29. 1. 1910., ABiH, ZMF, Präs., 150/1910.; P. VRANKIĆ, Religion und Politik, str. 697-698.

69 Varešanin Ministarstvu, 29. 1. 1910., ABiH, ZMF, Präs., 150/1910.; P. VRANкIĆ, Religion und Politik, str. 698.

70 Varešanin Ministarstvu, 29. 1. 1910., ABiH, ZMF, Präs., 150/1910.

71 Varešanin Ministarstvu, 29. 1. 1910., ABiH, ZMF, Präs., 150/1910.; P. VRANкIĆ, Religion und Politik, str. 698. 
molbu u kojoj su tražili državno jamstvo da će minimalni prihod svakoga svećenika biti $2000 \mathrm{kr}^{72}$

Nedugo potom, 10. ožujka 1910., Stadler je vladi "kao nadopunjak" dopisu Vrhbosanskog ordinarijata od 19. studenoga 1910. poslao izjave katolika iz dijecezanskih župa Banjolučke i Trebinjske biskupije koji su se također očitovali za uvođenje kongrue uz napomenu "da su banjalučki i mostarski ordinarijat odobrili misao, da se bar u svjetovnim župama svećenička kongrua zavede". ${ }^{73} \mathrm{O}$ ovome je civilni adlatus I. Benko, uz analizu koje su župe bile $z a$ a koje protiv, izvijestio Zajedničko ministarstvo financija 30. ožujka 1910. Kako se vidi iz Benkova dopisa gradsko stanovništvo i u ovim biskupijama bilo je protiv uvođenja kongrue. ${ }^{74}$

Dobivši vladine dopise, ministar Burián odgovorio je 29. travnja 1910. Istaknuo je kako predloženi vladin postupak, da se u pojedinim dijecezanskim župama osnuju odbori koji bi odlučivali o propisanom doprinosu pojedinih župa za vjerske potrebe, čiji bi zaključci pod određenim uvjetima od vlade mogli imati egzekutivni karakter, po sebi nije neprovediv. Ovlastio je vladu da u tom smislu nastavi pregovore s nadbiskupom Stadlerom napomenuvši da bi se odbori, ne samo u gradskim i mješovitim, nego i u seoskim župama, trebali postaviti jer se pisane izjave koje su došle sa seoskih župa, koje su, kako piše ministar, nastale pod izravnim utjecajem svećenstva, ne mogu smatrati dovoljnom obveznom osnovom odobrenju državne potpore. Ministar je zaključio da bi jedinstveno reguliranje kongrue moglo slijediti samo preko zemaljskoga zakona ili na temelju, odnosno preko inicijative od Stadlera zasnovane katoličke vjerske autonomije. ${ }^{75}$ Dobivši odgovor ministra Buriána vlada je o njemu obavijestila Vrhbosanski nadbiskupski ordinarijat 6. svibnja 1910. ${ }^{76}$

U međuvremenu se dogodilo još nešto važno. Stadler je 18. listopada 1909. predao Zemaljskoj vladi novi prijedlog statuta o katoličkoj autonomiji. Članak 19. govori o uređenju kongrue. Prema iznesenu

72 Varešanin Ministarstvu, 29. 1. 1910., ABiH, ZMF, Präs., 150/1910.

73 Stadler Vladi, 10. 3. 1910., ABiH, ZVS, Präs., 2161/1910.

74 Benko Ministarstvu, 30. 3. 1910., ABiH, ZMF, Präs., 431/1910.; P. Vrankić, Religion und Politik, str. 699.

75 Burián Vladi, 18. 4. 1910., ABiH, ZVS, Präs., 2161/1910.; P. VRAnkić, Religion und Politik, str. 699.

76 Vlada Ordinarijatu, 6. 5. 1910., ABiH, ZVS, Präs., 2161/1910.; AVN, 591/1910. 
prijedlogu fond za "uzdržavanje župnika i kapelana u Bosni i Hercegovini" trebao bi se sastojati: a) od poreza bosanskohercegovačkih katolika u iznosi od 10\%; b) od novca koji je do sada dostavljan kao potpora za uzdržavanje župnika i c) od novca koji se davao župnicima za katehizaciju u školama. ${ }^{77}$ Nadbiskup se 28. siječnja 1910. sastao u Beču s ministrom Buriánom te razgovarao o statutu. Nadbiskupu je tom prilikom jasno rečeno da statut od njega predstavljen nije prikladan za pregovore ni po sadržaju ni po formi jer mu nedostaje ono bitno a to je sudjelovanje laičkog elementa. Savjetovano mu je da s pomoću pravnih stručnjaka izradi novi prijedlog statuta koji će uzeti u obzir stajališta do kojih se došlo tijekom razgovora te ono što je već utvrđeno u srpsko-pravoslavnom i muslimanskom statutu a primjenjivo je na Katoličku Crkvu. ${ }^{78}$ "Istom, kad se ovo dogodi i na autentičan način stavi na papir, tako da mjerodavni faktori domaćeg dijecezanskog i redovničkog klera, kao i zato izabrani zastupnici katoličkog stanovništva i inteligencije u čitavoj zemlji izjave se sporazumnim sa nacrtom statuta, vlada će pobliže razmotriti taj nacrt i ući u pojedinačnu raspravu te utvrditi nacrt statuta o autonomiji." ${ }^{79}$ Što se tiče članka o kongrui, on je vladi u predloženoj formi bio neprihvatljiv, te je predložila da bi ga trebalo preraditi "u smislu analognih odredaba pravoslavnog i muslimanskog statuta". ${ }^{80}$

$\mathrm{Na}$ spomenute prijedloge austrougarske uprave nadbiskup Stadler nije odgovarao niti je više poduzimao ikakve korake oko autonomije. ${ }^{81}$ Također nije odgovorio ni na vladin prijedlog od 6. svibnja 1910., odnosno na uvjete koje je bio postavio ministar Burián za daljnje pregovore oko kongrue. Kako piše sastavljač studije Kongruafrage in BOSNIEN und HERCEGOVINA, nadbiskup Stadler je bio protiv ovoga vladina prijedloga jer je smatrao protivno kanonskom pravu

77 L. ĐAković, "Nastojanje nadbiskupa Stadlera", str. 252-253; P. VRANkić, Religion und Politik, str. 698.

78 Kongruafrage in BOSNIEN und HERCEGOVINA. - Studie, ABiH, ZVS, Präs., 4151/1912., str. 18-19; L. ĐAKOviĆ, "Nastojanje nadbiskupa Stadlera", str. 244-245.

79 Burián Vladi, 10. 2. 1910., ABiH, 339 - od 20. II. 1910. - citirano prema: L. ĐA Ković, "Nastojanje nadbiskupa Stadlera", str. 245.

80 L. ĐA коvić, "Nastojanje nadbiskupa Stadlera", str. 253.

81 Kongruafrage in BOSNIEN und HERCEGOVINA. - Studie, ABiH, ZVS, Präs., 4151/1912., str. 19. 
uvođenje laika u upravu župa pa tako i izbor odbora u župama koji bi raspravljali i odlučivali o uvođenju kongrue. ${ }^{82}$

\section{Pokušaj posredstvom Svete Stolice 1910. godine}

Kako se može razabrati iz daljnjih koraka, Stadler je odustao od gore navedenih prijedloga, odnosno mogućnosti uređenja kongrue samo za župe svjetovnoga klera te je nastavio inzistirati da se kongrua uvede za sav kler. Budući da je bio svjestan da franjevci na to ne će rado pristati, pokušao je intervenirati kod Svete Stolice da se na njih učini pritisak da od Zemaljske vlade zatraže uvođenje kongrue. Takvu mogućnost Stadler je spomenuo još u razgovoru s civilnim doglavnikom I. Benkom početkom listopada 1909., ali ju je tada još držao u pričuvi. ${ }^{83}$ Razlog Stadlerova obrata vjerojatno je bio nedovoljna dostatnost sredstava za dolično uzdržavanje klera koja bi se prikupila samo na svjetovnim župama i različitost prakse koja bi među klerom i narodom mogla stvarati probleme. Ovakav zaključak može se izvući iz njegova pisma državnom tajniku Svete Stolice kardinalu Merry del Valu od 18. svibnja 1910. Naime, pišući kardinalu kako se, da bi se poboljšalo materijalno stanje klera, došlo na ideju da se primanja u "naturi" zamijene izravnim porezom i, moleći ga da Sveta Stolica obveže franjevce da se ne opiru uvođenju kongrue, navodi da bi se ovim riješilo dvoje: 1 . ujednačila bi se primanja klera dokidanjem velikih razlika u prihodima među različitim župama i 2 . osiguralo bi se dovoljno sredstava za uzdržavanje svih. ${ }^{84}$ Prije ovoga Stadle-

82 "Erzbischof dr. STADER ist nämlich, weil dies dem kanonischen Rechte widerspricht, gegen die Institution der Pfarrgemeinden mit Zuziehung des Laienelementes and er Teilnahme der Pfarrverwaltung und gegen Alles was einer solchen Institution ähnlich wäre, infolge dessen auch gegen die Wahl der angeregten Komitees in den Pfarren." Kongruafrage in BOSNIEN und HERCEGOVINA. - Studie, ABiH, ZVS, Präs., 4151/1912., str. 19.

83 "Eher scheint er zu dem, vorläufig allerdings nur in Reserve gehaltenen Mittel greifen zu wollen, auf die Franziskaner durch Rom einen Druck ausüben zu lassen." Benkovo izvješće o susretu sa Stadlerom i Šarićem, 6. 10. 1909., ABiH, ZMF, Präs., 1973/1909.

84 "In primo luogo mi pregio di esporre la questione della congrua del clero. Per migliorare le condizioni economiche del nostro clero si era venuti al'idea di abolire la contribuzione 'in natura' dei fedeli in uso finora e di provvedere al sostentamento del clero per mezzo di imposte dirette, legalmente introdotte e riscosse dal Governo stesso dai sudditi cattolici fissando come principio, che il minimo salario fosse di 2000 corone austriache. In tal modo si ottene- 
rova interventa intervenirali su također 21 . travnja 1910. i svjetovni svećenici, njih 22. Uputili su molbu Svetome Ocu, obavijestivši ga o svom lošem materijalnom stanju koje bi se moglo riješiti uvođenjem kongrue, da svojom apostolskom vlašću prisili redovnički kler u Bosni i Hercegovini da i on od vlade zatraži njezino uvođenje. U molbi su istaknuli da je Zemaljska vlada, uvažavajući teške prilike u kojima se nalazi dijecezanski kler, izrazila spremnost riješiti pitanje kongrue samo za svjetovne svećenike kao što je to riješila za pravoslavce i muslimane ali, koliko je njima poznato, jedina prepreka koja stoji vladi na putu jest žestoko opiranje redovničkoga klera. U molbi su također naveli i razloge zbog kojih svjetovni kler želi kongruu a redovnički ne. Svjetovni kler želi kongruu jer živi bijedno iz razloga što je diobom župa dobio župe s manjim brojem vjernika ili gradske župe gdje su prihodi manji a redovnički kler ne želi jer je istom diobom dobio župe s većim brojem vjernika i to domaćih i s većim prihodima. Osim toga, redovnički kler u svojim župama ima razne crkvene posjede koji mu donose prihode te bi uvođenjem kongrue dobivali manje nego što su do sada dobivali. ${ }^{85}$ Iste razloge, zbog čega se franjevci opiru uvođenju kongrue, naveo je i nadbiskup Stadler kard. Merry del Valu u spomenutom pismu od 18. svibnja $1910 .{ }^{86}$

Nadbiskup Stadler se, u svibnju 1910., nalazio u Rimu ad limina apostolorum. Kako je u to vrijeme već postojao velik razdor između njega i političara iz Hrvatske narodne zajednice kojima su se priklonili franjevci, njegove susrete u Rimu pomno je pratilo austrougarsko veleposlanstvo pri Svetoj Stolici jer je austrougarska uprava bila živo zainteresirana da se ovaj slučaj ne rješava bez njezina utjecaja. Austrougarski veleposlanik pri Svetoj Stolici grof Nikola Széczen tražio je 12. svibnja 1910. upute svoga ministarstva kako se postaviti prema nadbiskupu, znajući da je Zemaljska vlada u Sarajevu s njim već

vano due interessi: 1. la remunerazione del clero diveniva ad essere più equa, eliminandosi le differenze enormi nei proventi fra diverse parrocchie, e 2 . si provvedeva in modo talqualmente sufficiente al sostentamento di tutti." Stadler Merry del Valu, 18. 5. 1910., AAV, AA. EE. SS., Austria, Pos. 1028, Fasc. 439, f. 64r.

85 Supplica diretta al S. Padre da 22 parroci (secolari) della Bosnia Erzegovina, nella quale chiedono l'introduzione della congrua parrocchaile. - 21 Aprile 1910., AAV, AA. EE, SS. Austria, Pos 1028, Fasc. 439, f. 65r-67r. Nacrt pisma na hrvatskom nalazi su u: AVN, b.b./1910. - 21. 4. 1910.

86 Stadler Merry del Valu, 18. 5. 1910., AAV, AA. EE. SS., Austria, Pos. 1028, Fasc. 439 , f. 64 rv. 
imala problema ${ }^{87} \mathrm{Iz}$ Beča mu je odgovoreno da je želja zajedničkoga ministra financija baruna Buriána da se postavi prema željama Zemaljske vlade iz Sarajeva. Što se tiče uvođenja kongrue napomenuto mu je da ona ne smije biti uređena protiv volje franjevaca, jer bez njihova pristanka to izgleda neprovedivo iz razloga što oni čine većinu pastoralnoga klera u Bosni. Dalje se navodi da su franjevci u ovome pitanju oporba nadbiskupu jer od namjeravana uvođenja kongrue ne očekuju nikakvu materijalnu korist. Također mu je napomenuto da vlada iz političkih razloga smatra da nije prikladno da se na franjevce čini pritisak preko Rima. ${ }^{88}$

Veleposlanik nije uspio od nadbiskupa Stadlera za vrijeme njegova boravka u Rimu izvući nikakve informacije pa se obratio kardinalu državnom tajniku Merry del Valu. Što se tiče kongrue kardinal mu je rekao da je nadbiskup Stadler tvrdio da je to želja vlade protiv koje on nema prigovora. Osim toga, da vlada želi urediti kongruu samo ako se ona odnosi na sve župe te da će protivljenje franjevaca njezinu uređenju nanijeti štetu svjetovnim svećenicima. Veleposlanik nije propustio, na temelju dobivenih podataka, kardinala "ispravno" informirati. ${ }^{89}$

Kardinal Merry del Val obratio se potom nunciju Belmonteu u Beču tražeći od njega da povjerljivo zamoli bivšeg ili sadašnjeg isusovačkog provincijala, za kojeg mu je nuncij već pisao da dobro poznaje prilike u Bosni, informacije o "postojećim pitanjima" između franje-

87 Széczen Aeherenthalu, 12. 5. 1910., HAUS-, HoF UND STAATSARCHIV (HHStA), Wien, F 26/K34 26, Bischöfe-Stadler 2, f. 3r; Zoran Grijak, Politička djelatnost vrhbosanskog nadbiskupa Josipa Stadlera, Hrvatski institut za povijest - Dom i svijet - Vrhbosanska nadbiskupija, Zagreb, 2001., str. 463.

88 "Congrua Frage soll nicht gegen den Willen der Franziskaner geregelt werden." Aeherenthal Széczenu, 17. 5. 1910., HHStA, F 26/K34 26, Bischöfe-Stadler 2, f. 1v. "Speziell in der Kongrua-Frage machen die Franziskaner dem Erzbischof Stadler Opposition, weil sie sich von der intendierten Kongruaregulierung keine materiellen Vorteile erhoffen. Diesbezüglich steht die Regierung auf dem Standpunkte, daß gegen den Willen der Franziskaner, die unter der Seelsorgegeistlichkeit im Lande überwiegen, eine allgemeine Kongruaregulierung untunlich erscheint und diese daher vorläufig auf die weltlichen Pfarren zu beschränken wäre. Eine Vergewaltigung der Franziskaner in dieser Beziehung auf dem Wege über Rom hält die Regierung aus politischen Gründen nicht für opportun." Aeherenthal Széczenu, 18. 5. 1910., HHStA, F 26/K34 26, Bischöfe-Stadler 2, f. 9v-10r; Z. GrIJAK, Politička djelatnost, str. 643-644.

89 Széczen Aeherenthalu, 24. 5. 1910., HHStA, F 26/K34 26, Bischöfe-Stadler 2, f. 14rv. "Ich habe selbstverständlich Anlass genommen auf Basis der mir mitgetheilten Daten den Sachverhalt richtig zu stellen," f. 14v. 
Milenko Krešić - Nastojanja nadbiskupa Stadlera oko uvođenja kongrue...

vaca i svjetovnoga klera i nadbiskupa Stadlera. ${ }^{90}$ Provincijal je zamolio jednog od svojih redovnika koji se nalazio u Bosni da sačini izvješće. Redovnik je izvješće napisao i pročitao svome superioru koji ga je odobrio kao nepristrano i odgovarajuće istini. ${ }^{91}$ Izvješće je došlo do nuncija koji ga je zajedno sa svojim pismom poslao državnom tajniku 18. lipnja 1910. Jedno od "postojećih pitanja" na koje se osvrnuo isusovac izvjestitelj bilo je pitanje kongrue, čije je uvođenje smatrao vapijućom potrebom (un bisogno che grida). Izvjestitelj dalje nastavlja da svećenici u ovim krajevima žive od prihoda naroda koji je veoma siromašan te da je njihov život nerijetko užasan zbog čega i "rijetki od njihovih studenata" žele postati svećenici. Franjevci koji su zadržali bolje župe ne osjećaju toliko siromaštvo kao svjetovni svećenici. Osim toga, kako piše izvjestitelj, franjevci bolje prikupljaju prihode od vjernika ali se u prikupljanju služe jednim običajem koji se jedva može tolerirati. Taj običaj je bio da svaka obitelj mora godišnje platiti svome župniku određenu svotu prema broju članova obitelji i to se čini o uskrsnim ispovijedima. Kada otac obitelji plati što je dužan, dobije ispovjednu ceduljicu, odnosno dopuštenje da se može ispovjediti. Tu ceduljicu mora pokazati ispovjedniku prije ispovijedi. Često se događa da otac obitelji ne uzme ceduljicu ili što ne će ili što ne može platiti. Navodi primjer da je "jučer" ispovjedio jednog seljaka koji se nije ispovijedao osam godina. Na njegovo pitanje zašto, odgovorio mu je da je imao malu djecu i da nije mogao platiti župniku koji mu je zbog toga uskratio odrješenje. Prikupljajući prihode na ovaj način i držeći bolje župe, franjevci dobivaju od naroda više nego što bi dobivali uvođenjem kongrue i zato joj se protive. ${ }^{92}$

Državno je tajništvo očito sadržaj ovog izvješća poslalo generalnoj upravi franjevačkoga reda u Rimu koja je potom o predmetnoj stvari tražila mišljenje provincijala Mišića. Pišući generalnom delegatu reda 22. srpnja 1910. Mišić je za nadbiskupovo "loše držanje" prema franjevcima okrivio isusovce koji su kivni na franjevce zbog nekih njihovih povijesnih razmirica. ${ }^{93}$ Što se tiče kongrue piše da franjevci

90 Merry del Val Belmonteu, 28. 5. 1910., AAV, Arch. Nunz. Vienna, Vol. 729, f. 670rv.

91 Allegato al Rapporto ad dei 18. Giugno 1910. Belmonte Merry del Valu, 18. 6. 1910., AAV, Arch. Nunz. Vienna, Vol. 729, f. 690rv.

92 Allegato al Rapporto ad dei 18. Giugno 1910., Belmonte Merry del Valu, 18. 6. 1910., AAV, Arch. Nunz. Vienna, Vol. 729, f. 689r-690r.

93 Mišić generalnom delegatu, 22. 7. 1910., CGFM, Roma, Bosnia SK 161, f. 472. 
nisu za nametanje poreza narodu nego su da i dalje daje u naturi jer je narodu tako lakše, a osim toga svećenik na taj način ostaje bliži narodu, odnosno više će se brinuti za narod. ${ }^{94} \mathrm{Na}$ pritužbe o uskrsnim ceduljicama odgovara da su one uvedene od davnine zbog brige otaca franjevaca da vjernici ne zanemare i umru bez uskrsne ispovijedi i pričesti. Ceduljica bi se davala ocu obitelji, koji bi se na osnovi nje upisivao da je ispovjeđen. One koji nisu bili ispovjeđeni župnik bi s ambona pozvao da izvan uskrsnoga vremena dođu i ispune svoju obvezu. Takvi bi se zbog svoje nemarnosti izvrgli sramoti naroda te su na taj način gotovo svi bili prisiljeni na uskrsnu ispovijed i pričest. Osim za oca obitelji ceduljice bi se tražile i za ostale članove obitelji kako bi ih se ispitalo u vjerskom znanju i tako dobro poučene u vjeri pripuštalo bi ih se ispovjedi i pričesti. ${ }^{95}$ Provincijal navodi da je istina da za tu ceduljicu, dodajući da takva praksa postoji i u drugim biskupijama koje graniče s Bosnom i Hercegovinom, otac obitelji treba

94 Mišić generalnom delegatu, 22. 7. 1910., CGFM, Roma, Bosnia SK 161, f. 474r$475 \mathrm{r}$.

95 "Ultimario insurgunt ex oblaterant, franciscanos cum schedulis com. paschalis facere malversationes. Esti summa et effrons injuria nec non calumnia. Quid veritatis? Patres nostri ab antiquitate summe curarunt ut fideles quotquot sunt, speciatim autem patres familias confes. et communion. paschalem non negligent. Sic multum tenebatus de commun. et confes. paschali, ut illam non peragertes mortui sepeliebentur extra numerum bonorum vis angulo separato. Et ista vigilantia firma et durans permaneat, erant introductae schedulae primo patrum familiarum, qui advenerant suo parocho, dein ante vel post confessionem protocollo inscribebatur qua confessi. Sic inscripti habebantur pro confessis, e contra non inscripti pro non confessis. Exemte tempore Paschali ex ambona admonnita pastor. non confessi accedant proxime s. tribunali, satisfaciant obligationi, consulent saluti animae. Audientes vocem veniebant et satisfaciebant, negligentes statu dominica pro incutiendo pudore et timore publice denunciebantur, sic judicio ex opprobrio populi tradebantur, quod regulam habuerat uti etiam. Maxime negligentes quasi coacti erant accedere confes. et communioni pasch. Reliquum populi praeter patres familias etiam obtinebant schedulas, ista ex ratione, ut tantumodo examinati e doctrina, bene in religione instructi permittebantur ad confes. et com. Sine schedula, ejusmodi habebantur ut sufficienter non instructi, remittebanturque ut edocti melius tenuo accedant. Ergo uti videt, schedulae optimum finem habebant, non vero uti infamans auctor torturae aut malversatione habet. Est quidem verum pro esjusmodi schedulis uti in aliis diocesibus confinibus Bosnae Ercegovina, contribuit Pater familias 8 . aut 20. hell. secundum loca, ast sic, qui non valent aut non possunt nec istud conferre debent. Non habentibus gratis conceditas schedula." Mišić generalnom delegatu, 22. 7. 1910., CGFM, Roma, Bosnia SK 161, f. 475r-476r. 
dati 8 ili 20 helera ovisno o mjestu, ali oni koji nisu mogli ili nisu htjeli, nisu ni morali platiti. ${ }^{96}$

Što se tiče ceduljica, izvješća o. isusovaca i o. provincijala ne podudaraju se, odnosno bolje reći proturječe jedno drugom. Genezu i prvotni smisao cedulje nije bilo moguće utvrditi, ali ostaje činjenica, koju mogu potvrditi i živi svjedoci, da su ceduljice postojale sve do u novije vrijeme i da su se plaćale. Je li zbog njih bilo uskraćivanja ispovijedi i u kojoj mjeri na osnovi raspoložive arhivske građe, nije bilo moguće točno utvrditi. Bez obzira na sve, optužbe su postojale.

Zbog problema s politikom i franjevcima, Stadler se ponovo zaputio u Rim u listopadu 1910. kako bi tražio podršku od Svete Stolice. I tada je jedna od tema njegovih razgovora bila kongrua. Nadbiskup je, kako piše otpravnik poslova austrougarskoga veleposlanstva pri Svetoj Stolici grof Eduard Pálffy, opetovano zatražio od Svete Stolice da učini pritisak na franjevce kako bi popustili uvođenju kongrue. ${ }^{97}$ Sveta je Stolica rješenje ovoga pitanja, kao i ostalih zbog kojih je nadbiskup boravio u Rimu, odlučila pridržati sebi. O tome je papa Pio X. 28. studenoga 1910. obavijestio nadbiskupa Stadlera, biskupe sufragane i dvojicu franjevačkih provincijala. ${ }^{98}$ Sveta je Stolica kasnije slučaj povjerila apostolskom delegatu Pierreu Bastienu koji će se ovom problematikom baviti od 1911. do 1914. godine.

96 Mišić generalnom delegatu, 22. 7. 1910., CGFM, Roma, Bosnia SK 161, f. 476r.

97 Pálffy Aeherntalu, 13. 10. 1910., HHStA, F 26/K34 26, Bischöfe-Stadler 2, f. 161rv.

98 "Excitata inter Bosniae Erzegovinae fideles discordia, causa socialis actionis, [...]. Multo autem accidit molestiis, quod clerus uterque a studiis partium non abstineat; quin etiam in medio opinionum aestu animorumque disscuse, veterem quaestionem instauraverit de cura paroeciarum, novamque excitarit de inducenda congrua paroeciali praebenda. Itarum conflictationum, unde tam gravia clero populoque demna proveniunt, at causa tollatur omnis, Nos pro supremi Patris ac Pastoris quo fungimur munere, ac pro singulari amore, quo clerum et fideles Bosniae Erzegovinae complectimur, instantibus etiam plurimis ex iis regionibus, ut praesenti offensioni occurratur, quaestiones istas omnes Ipsi Nobis cognoscendas dirimendasque recipimus, imposito super iisdem utrique clero silentio." Pio X. Stadleru i ostalima, 28. 11. 1910., AAV, Segr. Stato, Rubrica 247, Fasc. 10, 1914., f. 4r-5r. 


\section{Zaključak}

Postavši vrhbosanskim nadbiskupom Josip Stadler pokušao je odmah na početku svoje službe urediti pitanje kongrue, odnosno dostojnog uzdržavanja svećenika na način kako je to bilo uređeno u ostalom dijelu Monarhije, tj. u dogovoru s državnim vlastima. Prvi njegov pokušaj u tome smislu zabilježen je početkom 1882. a zadnji, prije nego što je ovo pitanje Sveta Stolica pridržala sebi, 1910., s tim da je najintenzivnije na njemu radio između 1905. i 1910. predloživši vladi dva projekta o "katoličkoj autonomiji" u kojima je jedno od temeljnih pitanja bilo rješavanje problema kongrue. Iz jačine Stadlerova inzistiranja na ovom pitanju vidi se da je za njega kao nadbiskupa ono bilo veoma bitno. S njim, ne samo da bi se riješilo pitanje doličnog uzdržavanja župnika, nego i "loša praksa" koja se događala po župama, nastala, s jedne strane, zbog nemarnosti naroda da daje župniku ono što je dužan, a s druge strane zbog preuzetnosti župnika da traži od naroda ono što mu ne pripada i da ono što mu pripada ne traži na nedoličan način. Osim toga, ne manje bitno za Stadlera kao ordinarija, rješenjem kongrue poboljšao bi se materijalni položaj dijecezanskoga klera koji je, redovito živeći na malim župama, jer takve su mu dopale raspodjelom, živio vrlo bijedno. Glavni kočničari Stadlerovih nastojanja bili su franjevci. Zbog njih na kraju kongrua nije ni uvedena. I oni su imali svoje razloge. Raspodjelom župa dobili su bolje župe i imali su veća primanja ali i obveze prema samostanima i odgojnim zavodima koji su se uglavnom uzdržavali od prihoda sa župa. Procijenili su da bi se uvođenjem kongrue njihova primanja umanjila te bi došla u pitanje opstojnost samostana i odgojnih zavoda, na kraju opstojnost i same provincije te su se cijelo vrijeme uspješno, navodeći u javnosti druge razloge a u svojoj internoj komunikaciji navedene, opirali uvođenju kongrue. Austrougarska vlast koja je bila neizostavan čimbenik u rješavanju ovoga problema ponašala se politički pragmatično. $S$ jedne strane i ona je smatrala da bi ovaj problem trebalo riješiti a s druge strane bila je svjesna da se on ne može zadovoljavajuće riješiti bez volje franjevaca koji su činili većinu svećenstva u Bosni i Hercegovini i pastorizirali (kontrolirali) većinu katoličkoga stanovništva. K tome još morala je voditi računa o pravoslavnima i muslimanima koji su problem uzdržavanja svojih vjerskih službenika riješili kroza status o autonomiji te primijeniti ista načela i u odnosu na katolike. Ipak, svjesna teška položaja dijecezanskoga klera, ponudila je Stadleru mogućnost da se pitanje kongrue riješi samo za dijecezanski kler ali pod istim uvjetima kako su to riješili pravoslavci i muslimani, tj. da vjernici koji će biti oporezivani 
dobiju odlučujuću ulogu preko odbora u župama u pitanju uvođenja i uređenja kongrue. Za Stadlera je ovo bilo neprihvatljivo jer je bilo protivno kanonskim propisima. Shvativši da se stvar ne može riješiti s vlastima, ali i da bez franjevaca nema kompletna rješenja, odlučio je zatražiti pomoć od Svete Stolice u smislu da ona učini pritisak na franjevce da i oni zatraže od vlade uvođenje kongrue. Sveta Stolica, shvativši da ovaj problem stvara razdor u bosanskohercegovačkom kleru, rješenje pitanja kongrue pridržala je sebi. Njime će se kasnije baviti apostolski delegat P. Bastien koji je boravio u Bosni od kraja 1910. do početka Prvoga svjetskog rata, tj. do kraja lipnja 1914.

I na kraju, Stadlerov je pokušaj bio hvale vrijedan, franjevački razumljiv. Zbog nedostatka međusobna povjerenja i razumijevanja te uskogrudnosti franjevaca, koji su na prvo mjesto stavljali svoj interes, najviše su izgubili najslabiji, dijecezanski svećenici na malim župama, umirovljenici i svećenici nesposobni za službu. 